\title{
Using the "mean temperature of the catch" to assess fish community responses to warming in a temperate lake
}

\author{
Külli Kangur $\cdot$ Erki Tammiksaar $\cdot$ Daniel Pauly
}

Received: 26 December 2020 / Accepted: 24 June 2021 / Published online: 14 July 2021

(C) The Author(s) 2021

\begin{abstract}
This contribution applies the "mean temperature of the catch" (MTC) concept of Cheung et al. (Nature 497:365-368, 2013) to fish catch data for Lake Peipsi, Estonia/Russia, covering the years 1931 to 2019. The preferred temperature of each of the ten target fish species was obtained from the literature, and combined with the species-specific catch data to obtain MTC values for each year. The analysis of the MTC time series thus obtained with a segmented regression yielded two trend lines, one horizontal at $14.5^{\circ} \mathrm{C}$ (1931-1986), and the other (1987-2019) ascending with a slope $0.85{ }^{\circ} \mathrm{C} \cdot \mathrm{decade}^{-1}$. Overall, the segmented regression model explains over half of the variance of the MTC data set (multiple $R^{2}=0.53$; adjusted $R^{2}=0.51$ ). Lake surface water temperatures correlate with MTC, even though weakly $(r=0.30)$,
\end{abstract}

\footnotetext{
K. Kangur

Centre for Limnology, Institute of Agricultural and Environmental Sciences, Estonian University of Life Sciences, Tartumaa, Estonia

E. Tammiksaar

Centre for Science Studies, Estonian University of Life

Sciences, Tartu, Estonia

E. Tammiksaar

Department of Geography, University of Tartu, Tartu, Estonia

D. Pauly $(\bowtie)$

Institute for the Oceans and Fisheries, University of British

Columbia, Vancouver, BC, Canada

e-mail: d.pauly@oceans.ubc.ca
}

when considering a 2-year time lag. The fish community of the shallow Lake Peipsi reacts more strongly to temperature changes than marine ecosystems so far studied using the MTC.

Keywords Long-term changes in fish catch . Preferred temperature of fish - Water temperature change $\cdot$ Fish community composition $\cdot$ Large shallow lake

\section{Introduction}

Fish populations in northern latitude lakes are strongly impacted by climate warming (e.g., Jeppesen et al. 2012; van Dorst et al. 2019). As ectotherms, freshwater fish are directly affected by changes in water temperature. Moreover, temperature indirectly influences the volume of suitable habitat in a lake in addition to its direct physiological effects on fish (Tanentzap et al. 2020). With global warming, a greater dominance of warm-water fish can be expected in fish communities and, consequently, in fisheries catch. A signature of such climate change effects on global marine fisheries catch was first detected by Cheung et al. (2013). These authors proposed an index, the mean temperature of the catch (MTC), that is calculated from the average temperature preference of exploited species weighed by their annual catch. The MTC has been widely applied to describe warming impacts on fisheries catch in 
marine ecosystems (e.g., Keskin and Pauly, 2014; Liang et al. 2018; Dimarchopoulou et al., Identifying fisheries catch response to a warming ocean along a latitudinal axis in the western Pacific Ocean, in review), but applications to detecting signature of warming in freshwater fisheries have been wanting.

Assessing the effects of climate change on fisheries of global lakes is one of the challenges for sustainable management of inland waters (Kao et al. 2020). For the large shallow Lake Peipsi, Estonia/Russia, a recent analysis of how the lake surface water temperature (LSWT) responded to climate change showed that, although the average LSWT did not significantly increase from 1950 to 2018, it rose rapidly by about $0.5{ }^{\circ} \mathrm{C}$ in the winter seasons of the last decade (Öglu et al. 2020). Ice formation exhibits a delay of about 15 days since 2007, resulting in a longer open water period. Moreover, the winter 2019/2020 was the first since 1921 (the beginning of the observation history) without permanent ice cover on Lake Peipsi (Estonian Environmental Agency, 2020). According to Sharma et al. (2019), lake ice cover will severely diminish during the twenty-first century throughout the Northern Hemisphere, with many lakes no longer experiencing ice cover in winter. These climate change phenomena should strongly affect temperature-sensitive native fish in northern lakes such as Lake Peipsi.

The ecological effects of climate change are complex and lake specific and often depend on multiple interacting pressures (Craig et al. 2017). Many emerging changes in lake ecosystems are the result of complex interactions among a multitude of climatic factors, in addition to human activities and lake characteristics (Woolway et al. 2020). Current data on Lake Peipsi indicate that warm temperature extremes and synergistic interactions with continued cultural eutrophication have led to radical restructuring of fish community (Kangur et al. 2013). Eutrophication has caused deterioration of water quality and adverse changes in the whole ecosystem (Kangur et al. 2007a), e.g., excessive growth of algae, increased cyanobacterial blooms, low oxygen concentrations in water during night, increased sedimentation on spawning grounds, and fish kills. There have been several fish kills in the hot summers during heat waves in recent years (Kangur et al. 2005, 2013).

Lake Peipsi, with a large surface area, is important to Estonia because of its unique ecosystems and productive fisheries. Fish productivity of Lake Peipsi has historically been remarkably high (annual yield of about $65 \mathrm{~kg}$ per hectare), but currently, fish catches are only one-quarter of what they were in the middle of the nineteenth century (Tammiksaar and Kangur, 2020). At present, Lake Peipsi provides $85-90 \%$ of the total inland fish catch in Estonia, a catch that is important to both commercial and recreational fisheries (Orru et al. 2014). Shifts in the abundance of exploited species are expected to affect their availability to fisheries, as already observed in freshwater fisheries in Europe (see, e.g., Jeppesen et al. 2012; Sandström et al. 2014). In Lake Peipsi, the effects of high water temperatures (e.g., heat waves) in summer and extreme ice conditions on the abundance of some targeted species, e.g., lake (dwarf) smelt (Osmerus eperlanus) (Kangur et al. 2007b) and vendace (Coregonus albula) (Kangur et al. 2020), have been identified. However, a climate change signature for the entire fisheries of Lake Peipsi has so far not been detected.

The aim of the present study is to test the applicability of the MTC concept to Lake Peipsi, and by extension, to freshwater bodies in general. Specifically, we posit the hypothesis that the MTC for Lake Peipsi fishery catch has increased in the recent decades.

\section{Materials and methods}

\section{Study area}

Lake Peipsi $\left(57^{\circ} 51^{\prime}-59^{\circ} 01^{\prime} \mathrm{N} ; 26^{\circ} 57^{\prime}-28^{\circ} 10^{\prime} \mathrm{E}\right)$ is the fourth largest lake in Europe, located south of the Gulf of Finland on the border of Estonia and Russia (Fig. 1). Peipsi is a polymictic and shallow lowland lake (Table 1) with a surface area of $3555 \mathrm{~km}^{2}$ and a mean water level of $30 \mathrm{~m}$ above sea level (Jaani 2001). The submeriodionally elongated Lake Peipsi, with a maximum length of approximately $150 \mathrm{~km}$ and a width of $42 \mathrm{~km}$, consists of three limnologically different basins: Lake Peipsi sensu stricto (Lake Chudskoe in Russian; mean and maximum depth 8.3 and 12.9 m, respectively), Lake Lämmijärv (Lake Teploe; 2.5 and $15.3 \mathrm{~m}$ ), and Lake Pihkva (Lake Pskov; 3.8 and $5.3 \mathrm{~m}$ ). The catchment area (Table 1) consists of a flat lowland shared mainly between Estonia and Russia. Lake Peipsi's water level is not regulated, and 
Fig. 1 Location of Lake Peipsi and its three basins



its water level fluctuations are considerable, with an overall range of $3.04 \mathrm{~m}$ since 1921 (the beginning of the observation history) and a mean annual range of $1.15 \mathrm{~m}$ (Jaani, 2001).

Situated in the north temperate region, in the transition zone between a maritime and continental climate, Lake Peipsi experiences variable climatic conditions (Jaagus et al. 2017). Due to the lake's large surface area and its relative shallowness, waves affect the bottom during the ice-free period, and temperature stratification is therefore usually short and unstable; stratification may occur only during calm and windless days.

At present, the whole lake is eutrophic (Table 1), with a clear south-north gradient. The northern and deeper part is significantly poorer in nutrients than the southern, very shallow part (Kangur and Möls, 2008). Cultural eutrophication is still the main environmental problem for the transboundary Lake Peipsi (Fink et al. 2020).

Lake Peipsi is of great social and economic significance due to the importance of the fishery, which is a substantial sector of rural employment in the Peipsi region and an essential part of life in its coastal villages. Lake Peipsi is inhabited by 37 fish species (Kangur et al. 2008); no species have disappeared over the past century, and invasion of new species has not been recorded. Additionally, there have not been important stockings of fish during the time period considered here.

Unfortunately, information on Lake Peipsi is widely scattered, and consistent, long-term series 
Table 1 Selected characteristics of Lake Peipsi. Nutrient (surface water $0-1 \mathrm{~m}$ ), chlorophyll $a$ (integral sample), and water transparency values are presented as arithmetic means with minima and maxima (in brackets). All estimates correspond to the open water period (May-October) of 2010-2019 (after Kangur et al. 2020)

\begin{tabular}{ll}
\hline Property (unit) & Value \\
\hline Catchment area $\left(\mathrm{km}^{2}\right)$ & 47,800 \\
Lake area $\left(\mathrm{km}^{2}\right)$ & 3555 \\
Volume $\left(\mathrm{km}^{3}\right)$ & 25.07 \\
Mean depth $(\mathrm{m})$ & 7.1 \\
Maximum depth (m) & 15.3 \\
Hydrological turnover time (/year) & 2 \\
Total phosphorus $\left(\mathrm{mg} \mathrm{P} \cdot \mathrm{m}^{-3}\right)$ & $54(13-220)$ \\
Total nitrogen $\left(\mathrm{mg} \mathrm{N} \cdot \mathrm{m}^{-3}\right)$ & $748(250-2100)$ \\
Chlorophyll $a\left(\mathrm{mg} \cdot \mathrm{m}^{-3}\right)$ & $29(4-117)$ \\
Secchi disk water transparency $(\mathrm{m})$ & $1.4(0.4-3.8)$ \\
Trophic status $(\mathrm{OECD} 1982)$ & Eutrophic \\
\hline
\end{tabular}

of variable such as summarized in Table 1 are not available, thus limiting our ability to rigorously study the simultaneous impacts of multiple variables on its fish community. This also applies to fishing effort; however, long time series of the results of that effort, i.e., catches and their taxonomic composition, are available.

\section{Commercial fishery statistics}

To characterize long-term changes in the key fish populations of Lake Peipsi, we analyzed fish species composition and relative abundance of different fish species in the commercial catches in relation to environmental variables. Data on the fish population of Lake Peipsi for the time before 1931 do not seem to exist. The commercial fisheries statistics of Lake Peipsi, collected from fishermen by the state authorities, exist for the periods 1931-1940 (Soviet Union and Estonia) and 1950-2020 (Soviet Union, followed by Russia and Estonia). The period 1941-1949 is not covered due to World War II (WWII). The fish data are based on catches using a variety of fishing gear in different time periods and localities. Information on the main changes in fishing gear and fishing effort since the 1930s can be found in the work by Kangur et al. (2007c). The basic fishing gear used in Lake Peipsi was the local modifications of fence traps for the catch of vendace, lake smelt, and Eurasian perch (Perca fluviatilis), supplemented by gill nets for the catch of pike-perch (Sander lucioperca), Northern pike (Esox lucius), and common bream (Abramis brama). Fishing on Lake Peipsi has been intensive since historical times and some gears have remained the same for nearly the last two centuries (Tammiksaar and Kangur, 2020). Neither changes of gear type nor effort per gear are likely to have modified the annual catches too strongly, and thus that the annual catch is still a reliable indicator of fish community changes. In the 1930s, large fine-meshed twin-trawls (each towed by two motorboats) were used, their number amounting to 18 in 1939 (Pihu and Kangur, 2001).

During WWII, fishing almost ceased in Lake Peipsi, but in the 1950s, due to high demand for food, trawling was reintroduced. Thirty large pair of trawls were used in the lake in the mid-1950s (Pihu and Kangur 2001). At the end of the 1950s, trawls were replaced by another fine-meshed active fishing gear, Danish (bottom) seines (137 in 1966; Pihu and Kangur 2001). The number of bottom seines was gradually restricted from 1974 to 40 at present, 20 in both states, the Russian Federation and the Estonian Republic. Bottom seining is mostly employed for the catch of pike-perch and perch. Since 1994, the fishery is regulated according to the Estonian-Russian Fisheries Agreement (1994) and since 2000, quotas are established for commercial species.

Water temperature data

Daily data on LSWT in Lake Peipsi are available from the Mustvee hydrometric station (Fig. 1; $\left.58^{\circ} 50^{\prime} \mathrm{N}, 26^{\circ} 57^{\prime} \mathrm{E}\right)$ from 1924 onwards. At the hydrometric station, the LSWT in the near shore waters was measured using a Celsius mercury thermometer twice in $24 \mathrm{~h}$ at 8 a.m. and at 8 p.m. at a depth of $10 \mathrm{~cm}$ (Jaani et al. 2001). Since May 2009, an automatic station (VAISALA, MAWS110, and water temperature sensor QMT110) was used every hour for LSWT measurements. Daily values of LSWT in Lake Peipsi were obtained from the Institute of Meteorology and Hydrology of the Estonian Ministry of Environment and, since 1 June 2013, from the Estonian Weather Service of the Estonian Environment Agency.

Computation of the "mean temperature of the catch"

Table 2 shows the preferred temperature estimates that we attributed to each target species. 
Table 2 Preferred temperature $\left({ }^{\circ} \mathrm{C}\right)$ of the fish species in Lake Peipsi, with the central value in bold. "FishBase" refers to the database available from www.fishbase.org (Froese and Pauly, 2019)

\begin{tabular}{|c|c|c|c|}
\hline Species & $\begin{array}{l}\text { Preferred tempera- } \\
\text { ture }\left({ }^{\circ} \mathrm{C}\right)\end{array}$ & $\begin{array}{l}\text { Optimum range } \\
\left({ }^{\circ} \mathrm{C}\right)\end{array}$ & Remarks and sources \\
\hline Vendace (Coregonus albula) & $\begin{array}{l}7-9 \\
8\end{array}$ & $7-9$ & $\begin{array}{l}\text { Vendace has a cold-water thermal window } \\
\text { with a metabolic optimum } \sim 7-9^{\circ} \mathrm{C} \\
\text { (Ohlberger et al. 2008a; 2008b; Mehner } \\
\text { et al. 2010) }\end{array}$ \\
\hline Peipsi whitefish (Coregonus lavaretus) & $\begin{array}{l}10-11.5 \\
\mathbf{1 0 . 7 5}\end{array}$ & $\begin{array}{l}8-15 \\
4-16\end{array}$ & $\begin{array}{l}\text { Lehtonen (1996); } \\
\text { FishBase }\end{array}$ \\
\hline Lake (dwarf) smelt (Osmerus eperlanus) & $\begin{array}{l}5,14-15 \\
11.3\end{array}$ & $14-15$ & $\begin{array}{l}\text { Smelt prefer waters with the temperature of } \\
14-15{ }^{\circ} \mathrm{C} \text { (Vinni et al., 2004); average air } \\
\text { temperature at Tiirikoja (near Mustvee) } \\
\text { was } 5.2^{\circ} \mathrm{C} \text { in } 1981-2010 \text { (Estonian } \\
\text { Weather Service) }\end{array}$ \\
\hline Northern pike (Esox lucius) & $\begin{array}{l}17-19 \\
\mathbf{1 8}\end{array}$ & $\begin{array}{l}9-25 \\
10-28\end{array}$ & $\begin{array}{l}\text { Lethal/stress temperature range } 30-34{ }^{\circ} \mathrm{C} \text {; } \\
\text { Lehtonen (1996); FishBase }\end{array}$ \\
\hline Roach (Rutilus rutilus) & $\begin{array}{l}15.5-16.5 \\
b\end{array}$ & $\begin{array}{l}8-25 \\
11-20\end{array}$ & $\begin{array}{l}\text { Lehtonen (1996) } \\
\text { FishBase }\end{array}$ \\
\hline Common bream (Abramis brama) & $\begin{array}{l}17-18 \\
\mathbf{1 7 . 5}\end{array}$ & $\begin{array}{l}8-28 \\
10-24\end{array}$ & $\begin{array}{l}\text { Lehtonen (1996) } \\
\text { FishBase }\end{array}$ \\
\hline Burbot (Lota lota) & $\begin{array}{l}11.4-14.2 \\
10\end{array}$ & & $\begin{array}{l}11.4^{\circ} \mathrm{C} \text { (juveniles); } 14.2^{\circ} \mathrm{C} \text { (adults) } \\
\text { Hofmann and Fischer }(2002)\end{array}$ \\
\hline Eurasian perch (Perca fluviatilis) & $\begin{array}{l}16-17.5 \\
\mathbf{1 6 . 7 5}\end{array}$ & $\begin{array}{l}8-27 \\
10-22\end{array}$ & $\begin{array}{l}\text { Lehtonen (1996) } \\
\text { FishBase }\end{array}$ \\
\hline Pike-perch (Sander lucioperca) & $\begin{array}{l}14-21 \\
17\end{array}$ & $\begin{array}{l}12-30 \\
6-22\end{array}$ & $\begin{array}{l}\text { Lehtonen (1996) } \\
\text { FishBase }\end{array}$ \\
\hline Ruffe (Gymnocephalus cernuиs) & $\begin{array}{l}15-31.5 \\
21.73\end{array}$ & $\begin{array}{l}28-35 \\
10-20\end{array}$ & $\begin{array}{l}\text { Lehtonen (1996) } \\
\text { FishBase }\end{array}$ \\
\hline
\end{tabular}

Fish populations have multiple age classes that are responding to temperature in different ways over different timescales (van Dorst et al. 2019). Thus, the midrange of the temperatures where juveniles and adults occur was used in most cases. Larvae were ignored, as were "lethal" temperatures and the "optimal" temperatures for fast growth or other laboratorybased indicator. For example, for vendace, the only relevant temperature in Table 2 is $7-9{ }^{\circ} \mathrm{C}$. When the range is narrow, the arithmetic mean (i.e., the midrange, $8{ }^{\circ} \mathrm{C}$ for vendace) was taken for the MTC computation. When the range was wide, the geometric mean of the extrema was taken; thus, for Peipsi whitefish (Coregonus lavaretus), the geometric mean was $11^{\circ} \mathrm{C}$.

For the cold-stenothermal burbot (Lota lota), preferred temperature $11.4{ }^{\circ} \mathrm{C}$ for juveniles and $14.2{ }^{\circ} \mathrm{C}$ for adults has been proposed (Hofmann and
Fisher, 2002); the mean would be $12.8{ }^{\circ} \mathrm{C}$. On the other hand, burbot spawns in the winter under the ice cover, at temperature of under $4{ }^{\circ} \mathrm{C}$ (Tiitu and Vornanen, 2002; Pihu and Turovski, 2003). Thus, the temperature to use to MTC should be around $10{ }^{\circ} \mathrm{C}$, because the $4{ }^{\circ} \mathrm{C}$ estimate is not as well founded as the other estimates. Estimates of the preferred temperature of the species are documented in Table 2. For every year, we calculated the mean temperature of the catch from:

$$
\mathrm{MTC}=\sum \mathrm{Tj} * \mathrm{Cij} / \sum \mathrm{Cij}
$$

where $\mathrm{Tj}$ is the preferred temperature of species $\mathrm{j}$ and $\mathrm{Cij}$ is the catch of $\mathrm{j}$ (i.e., fish biomass in the catch) in year $i$. Then, using the commercial catch data by species, we calculated a mean preferred temperature of all fish caught in each year, weighted by the catch of each species. 
Data analysis

We used segmented regressions to test where the time series of MTC, which lasted from 1931 to 2019, could be described by one or several trend lines, as implemented in the "segmented" package in R Studio from https://cran.r-project.org/web/packages/segmented/ segmented.pdf). Catch data of 80 years (1931-1940 and 1950-2019) were included in the calculations. Also, we cross-correlated the mean temperature of Lake Peipsi and the MTC 0, 1, 2, and 3 years later.

\section{Results}

Trends in fish catch

According to the commercial fishery statistics, in the 1930s, the lake's annual fish yield was estimated as $33 \mathrm{~kg} \mathrm{ha}^{-1}$; in the $1980 \mathrm{~s}$, average annual yields, declined to $27 \mathrm{~kg} \mathrm{ha}^{-1}$; and during 2010-2020, yields further declined to $15 \mathrm{~kg} \mathrm{ha}^{-1}$. Smelt, vendace, pike-perch, and perch dominated commercial landings from Lake Peipsi at different time periods. In the 1930s, the commercial catches consisted mainly of smelt (43\% of total catch), roach $(16 \%)$, perch $(7 \%)$, bream $(7 \%)$, pike $(3 \%)$, and vendace (2\%). In the late 1930 s, pike-perch became another important commercial fish in the lake. From the 1950s to 1970 s, the catches of pike-perch decreased, but, in the late 1980s, the catches of pike-perch increased explosively (Kangur et al. 2020). At that time, vendace was of great importance for commercial fishing in Lake Peipsi. During 2010-2019, the fish species most targeted for harvest included perch $(31 \%)$, bream $(23 \%)$, pike-perch $(22 \%)$, and roach $(10 \%)$.

The main shift in the Peipsi fish community from cool-water species such as vendace, burbot, Peipsi whitefish, and lake (dwarf) smelt, whose abundance has declined markedly, toward more warm-water species like pike-perch and bream took place at the turn of the 1980/1990 decade (Kangur et al. 2007a, b, c; 2020), which coincided with the shift in the regional climate regime (Jaagus et al. 2017). In the late 1980s, a sharp decline in cool-water vendace population coincided with a major increase of warm-water pike-perch (Figure Kangur et al. 2020).

\section{Changes in MTC since 1930}

Figure 2 presents our key result, which is that our time series of MTC values can be split into two sharply different periods. The first period, from 1931 to 1986 , is characterized by strong, but trendless oscillation of MTC around a mean of MTC of $14.5^{\circ} \mathrm{C}$. The second period, from 1987 to 2019 , exhibits, in contrast, a significant increase of $0.085{ }^{\circ} \mathrm{C}$ per year, although here as well, there is much variation about the main, increasing trend. The mean MTC during the second period was around $16{ }^{\circ} \mathrm{C}$.
Fig. 2 Segmented regression of the time series of MTC, illustrating that the two trend lines (the horizontal 1931-1986 line, and the ascending 1987-2019 line) jointly explain over half of the variance in the data set (multiple $\mathrm{R}^{2}=0.53$; adjusted $\left.\mathrm{R}^{2}=0.51\right)$. The dotted line represents the means of July to September LSWTs in Lake Peipsi which, when shifted back 2 years, only weakly correlate with the MTC data $(\mathrm{r}=0.30, \mathrm{~d} \mathrm{f} .=77)$

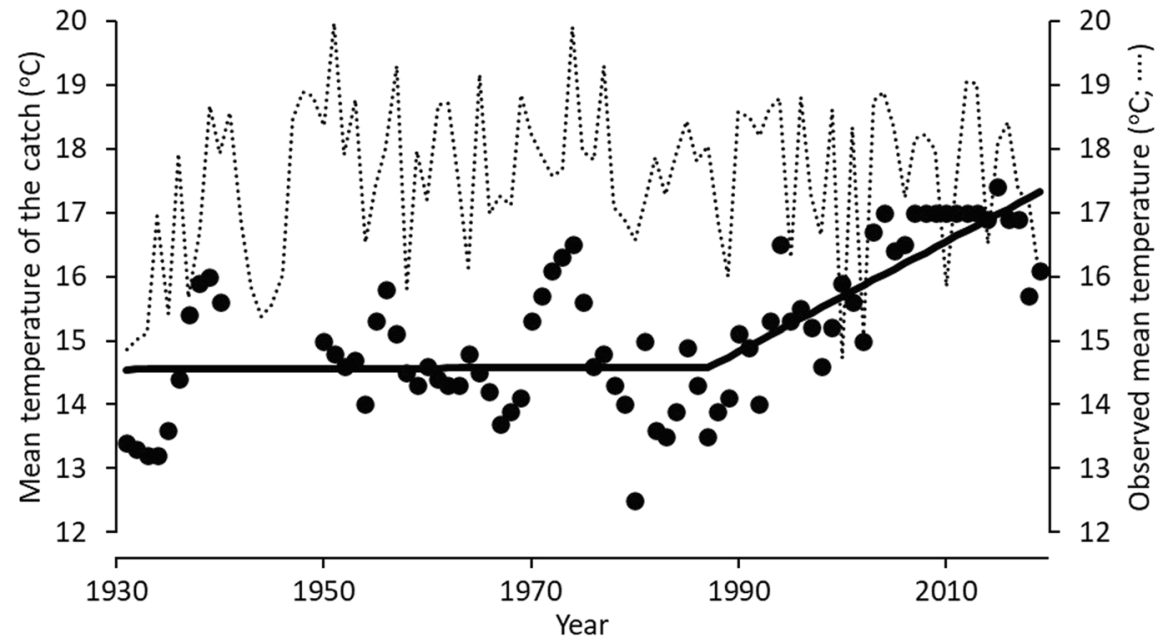


Correlations between lake temperature and the MTC

The highest correlation between the available temperature data and the MTC was $r=0.30$ for the mean June to September temperature with a 2 -year lag. The correlations with 1-year and 3-year lags had coefficients $r=0.24$ and 0.21 , respectively.

\section{Discussion}

This study shows that short periods of warming and cooling prior to the late 1980s have been reflected in the fish community composition of Lake Peipsi and hence in the MTC values. However, the MTC since the late 1980s exhibits a decidedly upward trend, the overall picture resembling the hockey-stick figure typical of global warming studies (Mann et al. 1998). The segment split around the 1990s and the positive slope of the catch temperature are probably linked to the shift in the regional climate regime in Europe (including Estonia) in the late 1980s (Woolway et al. 2017; Kotta et al. 2018) which manifested itself in Estonia with a sharp warming, mainly from the winter of 1988/1989 (Jaagus et al. 2017). This was reflected in the fish community of Lake Peipsi by a major shift from clean- and cool-water winter-spawning species such as vendace, whitefish, and burbot to more pikeperch and bream, which prefer productive warm and turbid waters (Kangur et al. 2007c).

Thus, fish species with a higher temperature preference (e.g., pike-perch) also dominate at higher productivity. Fish community in a large shallow lake such as Peipsi responds not so much to a long-term slow rise in yearly average water temperature as to short-term extreme weather events, e.g., heat waves, accompanied by cyanobacterial blooms, anoxia during night, and fish kills (Kangur et al. 2013). An abrupt increase in water temperature recorded at the end of 1980s was linked to the collapse of vendace population: the hot summer of 1988, which was accompanied by a severe cyanobacterial bloom and extensive fish kill, and the subsequent non-permanent ice cover and early ice-offs in 1989 and 1990 in Lake Peipsi were the main reasons for the disappearance of vendace from catches in 1991 (Kangur et al. 2020).

Also, other human stressors, such as continued eutrophication and overfishing, may affect the fish community in Lake Peipsi. Particularly, pike-perch is affected because larger specimens are almost completely removed and extensive use of finemeshed towed fishing gear (e.g., trawls replaced later by bottom seines) is killing young specimens of this fish in large quantities.

The MTC trend established for Lake Peipsi, of $0.852{ }^{\circ} \mathrm{C} \cdot$ decade $^{-1}$, appears to be much stronger than the MTC trends computed for the world's Large Marine Ecosystems, of $0.19{ }^{\circ} \mathrm{C} \cdot \mathrm{decade}^{-1}$ (Cheung et al. 2013), the Aegean Sea, of $0.25{ }^{\circ} \mathrm{C} \cdot \mathrm{decade}^{-1}$ (Keskin and Pauly, 2014), or even the East China and Yellow Seas, of $0.55^{\circ} \mathrm{C} \cdot \mathrm{decade}^{-1}$ (Liang et al. 2018).

Our findings suggest that MTC is a good indicator for comparing vulnerability to global changes of very different aquatic ecosystems (marine vs freshwater ecosystems) and helps to assess their sensitivity to global climate change. In fact, as suggested by Fig. 2, the MTC, which reflects how an entire fish community of a larger area responds to a variety of water temperature cues, may in some cases be a better indicator of warming than temperature itself. One explanation may be that climatic conditions in Estonia (situated in the transition area of Atlantic marine and Eurasian continental climate systems) are characterized by high spatio-temporal variations and the detection of trends and regime shifts in the climatic, hydrological, and ecological variables poses a great challenge (Jaagus et al. 2017).

Moreover, it well established that it is not elevated mean temperatures that impact fish community structure, but short-term extreme temperature events and their changing frequency (Easterling et al. 2000), whose impact may be completely masked when mean temperatures are used as explanatory variables. However, the weak correlation between the mean monthly temperature of Lake Peipsi and the MTC still generated an insight, as it improved slightly when a 2-year lag was applied. This is consistent with the fact that for a long time, the commercial catch in the lake consisted mainly of smelt, which have a short life cycle (Kangur et al. 2007b).

Finally, we note that, compared to marine ecosystems, the effects of climate change appear to be stronger in large shallow northern lakes. Shallow lakes are particularly sensitive to short-term extreme weather conditions, to which fish respond surprisingly quickly (Jeppesen et al. 2012; Kangur et al. 2013; 2020). This should be considered when 
designing a management system to ensure sustainable fisheries.

Acknowledgements We thank Ms. Elaine Chu for drafting Figs. 1 and 2.

Author contribution The work described has not been published before and is not under consideration for publication anywhere else. Its publication has been approved by all co-authors, as well as tacitly by the responsible authorities at the institutes where the work has been carried out. KK and ET contributed the fish catch data, and DP contributed the context; all authors reviewed and approved the final draft.

Funding Külli Kangur was supported by the Estonian Research Council (PRG 1266), and Erki Tammiksaar by Estonian Ministry of Education (P180276SPTL) and by the Estonian Research Council (PRG 346). Daniel Pauly acknowledges support from the Sea Around Us, itself supported by a number of philanthropic foundations, notably the Marisla, MAVA, Minderoo, Oak, David and Lucille Packard, and Rockefeller Foundations, as well as the Pew Charitable Trusts and the WWF.

\section{Declaration}

Data and code availability All the data used here are presented in the text and figures; no code was used.

The research reported herein did not involve human subject and/ or live animals or cell lines.

Conflict of interest The authors declare no competing interests.

Open Access This article is licensed under a Creative Commons Attribution 4.0 International License, which permits use, sharing, adaptation, distribution and reproduction in any medium or format, as long as you give appropriate credit to the original author(s) and the source, provide a link to the Creative Commons licence, and indicate if changes were made. The images or other third party material in this article are included in the article's Creative Commons licence, unless indicated otherwise in a credit line to the material. If material is not included in the article's Creative Commons licence and your intended use is not permitted by statutory regulation or exceeds the permitted use, you will need to obtain permission directly from the copyright holder. To view a copy of this licence, visit http://creativecommons.org/licenses/by/4.0/.

\section{References}

Cheung WWL, Watson R, Pauly D (2013) Signature of ocean warming in global fisheries catch. Nature 497:365-368. https://doi.org/10.1038/nature12156
Craig LS, Olden JD, Arthington AH, Entrekin S, Hawkins CP, Kelly JJ, Wooten MS (2017) Meeting the challenge of interacting threats in freshwater ecosystems: a call to managers. Elementa: Science of the Anthropocene, 5, 72. https://doi.org/10.1525/elementa.256

Easterling DR, Meehl GA, Parmesan C, Changnon SA, Karl TR, Mearns LO (2000) Climate extremes: observations, modeling, and impacts. Science 289:2068-2074

Estonian Environment Agency. (2020). 2019/2020 aasta talv on esimene talv alates vaatlusajaloo algusest 1921. aastal kui Peipsil püsivat jääkatet ei tekkinud. www.keskkonnaa gentuur.ee, 28 April 2020

Fink G, Burke S, Simis SGH, Kangur K, Kutser T, Mulligan M (2020) Management options to improve water quality in Lake Peipsi: insights from large scale models and remote sensing. Water Resour Manage 34:2241-2254. https://doi. org/10.1007/s11269-018-2156-5

Froese R, Pauly D (Eds) (2019) FishBase. World Wide Web electronic publication. www.fishbase.org. Version (12/2019) (last accessed 28.08.2020).

Hofmann N, Fisher P (2002) Temperature preferences and critical thermal limits of burbot: implications for habitat selection and ontogenetic habitat shift. Trans Am Fish Soc 131:1164-1172

Jaagus J, Sepp M, Tamm T, Järvet A, Mõisja K (2017) Trends and regime shifts in climatic conditions and river runoff in Estonia during 1951-2015. Earth Syst Dyn 8:963-976. https://doi.org/10.5194/esd-8-963-2017

Jaani A (2001) The location, size and general characterisation of Lake Peipsi and its catchment area. In: Nõges T (ed) Lake Peipsi: meteorology, hydrology, hydrochemistry. Sulemees Publishers, Tartu, Estonia, pp 10-17

Jeppesen E, Mehner T, Winfield IJ, Kangur K, Sarvala J, Gerdeaux D, Meerhoff M (2012) Impacts of climate warming on the long-term dynamics of key fish species in 24 European lakes. Hydrobiologia 694:1-39. https://doi.org/ 10.1007/s10750-012-1182-1

Kao YC, Rogers MW, Bunnell DB, Cowx IG, Qian SS, Anneville O, Young JD (2020) Effects of climate and land-use changes on fish catches across lakes at a global scale Nat Commun 11 (1). https://doi.org/10.1038/s41467-020-14624-2

Kangur A, Kangur P, Kangur K, Möls T (2007b) The role of temperature in the population dynamics of smelt Osmerus eperlanus eperlanus m. spirinchus Pallas in Lake Peipsi (Estonia/ Russia). Hydrobiologia, 584, 433-441. https://doi.org/10. 1007/s10750-007-0614-9

Kangur A, Kangur P, Pihu E, Vaino V, Tambets M, Krause T, Kangur K (2008) Kalad ja kalandus. In: Haberman J, Timm T, Raukas A (eds) Peipsi. Eesti Loodusfoto Publishers, Tallinn, Estonia, pp 317-340

Kangur K, Ginter K, Kangur A, Kangur P, Möls T (2020) How did the late 1980s climate regime shift affect temperaturesensitive fish population dynamics: case study of vendace (Coregonus albula) in a large north-temperate lake. Water 12, 2694. https://doi.org/10.3390/w12102694/w12102694

Kangur K, Kangur A, Kangur P, Laugaste R (2005) Fish kill in Lake Peipsi in summer 2002 as a synergistic effect of cyanobacterial bloom, high temperature and low water level. Proc Estonian Acad Sci Biol Ecol 54:67-80

Kangur K, Kangur P, Ginter K, Orru K, Haldna M, Möls T, Kangur A (2013) Long-term effects of extreme weather events and eutrophication on the fish community 
of shallow Lake Peipsi (Estonia/Russia). J Limnol 72(2):376-387. https://doi.org/10.4081/jlimnol.2013.e30

Kangur K, Möls T (2008) Changes in spatial distribution of phosphorus and nitrogen in the large north-temperate lowland Lake Peipsi (Estonia/Russia). Hydrobiologia 599:3139. https://doi.org/10.1007/s10750-007-9204-0

Kangur K, Park Y-S, Kangur A, Kangur P, Lek S (2007b) Patterning long-term changes of fish community in large shallow Lake Peipsi. Ecol Model 203:34-44. https://doi. org/10.1016/j.ecolmodel.2006.03.039

Kangur M, Kangur K, Laugaste R, Punning J-M, Möls T (2007c) Combining limnological and palaeolimnological approaches in assessing degradation of Lake Pskov. Hydrobiologia 584:121-132. https://doi.org/10.1007/s10750-007-0597-6

Keskin C, Pauly D (2014) Changes in the 'mean temperature of the catch': application of a new concept to the North-eastern Aegean Sea. Acta Adriat 55(2):213-218

Kotta J, Herkül K, Jaagus J, Kaasik A, Raudsepp U, Alari V, Arula T, Haberman J, Järvet A, Kangur K, et al (2018) Linking atmospheric, terrestrial and aquatic environments: regime shifts in the Estonian climate over the past 50 years. PLoS ONE, 13, e0209568. https://doi.org/10. 1371/journal.pone.0209568. eCollection 2018

Lehtonen H (1996) Potential effects of global warming on northern European freshwater fish and fisheries. Fish Manage Ecol 3:59-71. https://doi.org/10.1111/j.1365-2400.1996.tb00130.x

Liang C, Xian W, Pauly D (2018) Impacts of ocean warming on China's fisheries catch: application of the 'mean temperature of the catch.' Front Mar Sci 5:26. https://doi.org/10.3389/ fmars.2018.00026

Mann ME, Bradley RS, Hughes MK (1998) Global-scale temperature patterns and climate forcing over the past six centuries. Nature 392(6678):779-787. https://doi.org/10. $1038 / 33859$

Mehner T, Busch S, Helland IP, Emmrich M, Freyhof J (2010) Temperature-related nocturnal vertical segregation of coexisting coregonids. Ecol Freshw Fish 19:408-419. https://doi. org/10.1111/j.1600-0633.2010.00424.x

OECD (1982) Eutrophication of waters: monitoring, assessment and control. Paris, France: Organisation for Economic Co-operation and Development, Washington, D.C., Sold by OECD Publications and Information Center

Öglu B, Möls T, Kaart T, Cremona F, Kangur K (2020) Parameterization of surface water temperature and long-term trends in Europe's fourth largest lake shows recent and rapid warming in winter. Limnologica 82 . https://doi.org/ 10.1016/j.limno.2020.125777

Ohlberger J, Mehner T, Staaks G, Hölker F (2008a) Is ecological segregation in a pair of sympatric coregonines supported by divergent feeding efficiencies? Can J Fish Aquat Sci 65:2105-2113. https://doi.org/10.1139/F08-120

Ohlberger J, Mehner T, Staaks G, Hölker F (2008b) Temperature-related physiological adaptations promote ecological divergence in a sympatric species pair of temperate freshwater fish, Coregonus spp. Funct Ecol 22:501-508. https://doi.org/10.1111/j.1365-2435.2008.01391.x
Orru K, Kangur K, Kangur P, Ginter K, Kangur A (2014) Recreational ice fishing on the large Lake Peipsi: socioeconomic importance, variability of ice-cover period, and possible implications for fish stocks. Estonian J Ecol 63(4):282-298. https://doi.org/10.3176/eco.2014.4.06

Pihu E, Kangur A (2001) Fishes and fisheries management. In: Pihu E, Haberman J (eds) Lake Peipsi: flora and fauna. Sulemees Publishers, Tartu, Estonia, pp 100-111

Pihu E, Turovski A (2003) Burbot, Lota lota (L.). In E. Ojaveer E Pihu \& Saat T (Eds.), Fishes of Estonia (pp. 267-272). Tallinn, Estonia: Estonian Academy Publishers

Sandström A, Ragnarsson-Stabo H, Axenrot T, Bergstrand E (2014) Has climate variability driven the trends and dynamics in recruitment of pelagic fish species in Swedish Lakes Vänern and Vättern in recent decades? Aquatic Ecosyst Health Manag 17(4):349-356. https://doi.org/10. 1080/14634988.2014.975668

Sharma S, Blagrave K, Magnuson JJ, O'Reilly CM, Oliver S, Batt RD, ... \& Woolway IR (2019) Widespread loss of lake ice around the Northern Hemisphere in a warming world. Nat Clim Change 9, 227-231. https://doi.org/10. 1038/s41558-018-0393-5

Tammiksaar E, Kangur K (2020) Fish and fishing in Lake Peipsi (Estonia/Russia) since 1851: similarities and differences between historical and modern times. J Great Lakes Res 46:862-869. https://doi.org/10.1016/j.jglr.2020.04.005

Tanentzap AJ, Morabito G, Volta P, Rogora M, Yan ND, Manca M (2020) Climate warming restructures an aquatic food web over 28 years. Global Change Biology, 00, 1-15. First published: 11 September 2020 https://doi.org/10.1111/gcb. 15347

Tiitu V, Vornanen M (2002) Regulation of cardiac contractility in a cold stenothermal fish, the burbot Lota lota L. J Exp Biol 205:1597-1606

Van Dorst RM, Gårdmark A, Svanbäck R, Beier U, Weyhenmeyer GA, Huss M (2019) Warmer and browner waters decrease fish biomass production. Glob Change Biol 25(4):1395-1408. https://doi.org/10.1111/gcb.14551

Vinni M, Lappalainen J, Malinen T, Peltonen H (2004) Seasonal bottlenecks in diet shifts and growth of smelt in a large eutrophic lake. J Fish Biol 64:567-579. https://doi. org/10.1046/j.1095-8649.2003.00323.x

Woolway RI, Kraemer BM, Lenters JD, Merchant CJ, O'Reilly CM, Sharma S (2020). Global lake responses to climate change. Nat Rev Earth Environ 1(8). https://doi.org/10. 1038/s43017-020-0067-5

Woolway RI, Dokulil MT, Marszelewski W, Schmid M, Bouard D, Merchant CJ (2017) Warming of Central European lakes and their response to the 1980s climate regime shift. Clim Change 142:505-520. https://doi.org/10.1007/ s10584-017-1966-4

Publisher's note Springer Nature remains neutral with regard to jurisdictional claims in published maps and institutional affiliations. 